\title{
PELATIHAN EDUKATOR SEBAYA DAN PENGETAHUAN TENTANG GIZI SEIMBANG PADA SISWA DI SMUN 16 MAKASSAR
}

\author{
Nurhaedar Jafar ${ }^{1}$, Rahayu Indriasari ${ }^{1}$, Aminuddin Syam ${ }^{1}$, Yessy Kurniati ${ }^{2}$ \\ ${ }^{1}$ Program Studi Ilmu Gizi, FKM Unhas \\ ${ }^{2}$ Akademi Kebidanan, Ina U Makassar
}

Korespondensi, E-Mail : yessy.kurniati@gmail.com

\begin{abstract}
Adolescents are susceptible to nutritional problems for many reasons. One way to overcome these nutritional problems is to apply a balanced lifestyle nutrition. Peers become one of the prospective mediators to seek to change the value and behavior of health in adolescents. But before peer educators educate their friends, they need to improve their knowledge of balanced nutrition. This study would like to see the effectiveness of peer educator training on students' knowledge about balanced nutrition. This research was conducted in SMUN 16 Makassar. This study is an intervention study. Sampling was done by purposive sampling method and the number of selected samples was 40 students. Data analysis was performed with SPSS version 16 using paired T test to assess the difference of respondent knowledge before and after intervention. The results showed that after peer education training, there was an increase in respondents' knowledge of wellbalanced nutrition in the good category, from $17.5 \%$ before training to $70 \%$ after training, an increase of $52.5 \%$. knowledge of the respondents in the category quite decreased, ie from $45 \%$ before training to $25 \%$ after training, decreased by $20 \%$. Knowledge of respondents in the category of less decreased as well, ie from $37.5 \%$ before training to $5 \%$ after training, decreased by $32.5 \%$. From this study concluded, that the training is done effectively to improve the knowledge of respondents. Nutrition educators who have been trained are expected to transmit the knowledge they have to their peers. In addition, health promotion programs, especially balanced nutrition should be aggressively conducted in schools, considering the school is a place to form healthy behaviors that are expected to continue to survive until adolescence into adulthood phase
\end{abstract}

Key Word: adolescent, diet, nutrition, peer, training

\section{PENDAHULUAN}

Remaja adalah individu yang tengah mengalami perkembangan psikologi dan pola identifikasi dari anakanak menjadi dewasa. Pada remaja, terjadi peralihan dari ketergantungan sosial dan ekonomi yang penuh kepada orang tua menuju keadaan yang relatif lebih mandiri. Pertumbuhan fisik pada remaja menyebabkan mereka membutuhkan asupan nutrisi yang lebih besar dari pada masa anak-anak. Ditambah lagi pada masa ini, remaja sangat aktif dengan berbagai kegiatan, baik itu kegiatan sekolah maupun olahraga. Khusus pada remaja putri, asupan nutrisi juga dibutuhkan untuk persiapan reproduksi (Jafar, N. 2012). 
Remaja rentan mengalami masalah gizi karena berbagai hal. Pertama, remaja mengalami percepatan pertumbuhan dan perkembangan tubuh sehingga memerlukan energi lebih banyak. Kedua, remaja suka mengikuti perubahan gaya hidup dan kebiasaan makan yang belum tentu sehat. Ketiga, kehamilan, keikutsertaan dalam olah raga, kecanduan alkohol dan obat-obatan meningkatkan kebutuhan energi dan zat gizi(Jafar, N. 2012).

Berbagai faktor yang memicu terjadinya masalah gizi pada usia remaja antara lain adalah kebiasaan makan yang buruk di mana remaja makan seadanya tanpa mengetahui kebutuhan akan berbagai zat gizi dan dampak tidak dipenuhinya kebutuhan zat gizi tersebut terhadap kesehatan mereka, pemahaman gizi yang keliru yang menyebabkan remaja menerapkan pengaturan pembatasan makanan secara keliru sehingga kebutuhan gizi mereka tak terpenuhi, kesukaan yang berlebihan terhadap makanan tertentu terkait trend yang marak di kalangan remaja menyebabkan kebutuhan gizi tak terpenuhi. Selain itu promosi yang berlebihan melalui media massa yang dimanfaatkan oleh pengusaha makanan untuk mempromosikan produk mereka dengan cara yang sangat mempengaruhi remaja. Padahal, produk makanan tersebut bukanlah makanan yang sehat bila dikonsumsi dalam jumlah yang berlebihan.

Untuk mencegah timbulnya
masalah gizi tersebut, perlu disosialisasikan pedoman gizi seimbang yang bisa dijadikan sebagai pedoman makan, beraktivitas fisik, hidup bersih dan mempertahankan berat badan normal. Penyebarluasan informasi mengenai "pedoman gizi seimbang" selama ini dianggap kurang begitu berhasil, banyak masyarakat tidak mengetahui perubahan slogan empat sehat lima sempurna ke pedoman umum gizi seimbang meskipun perubahan itu telah terjadi hampir 20 tahun lamanya. Melihat hal tersebut perlu ada upaya untuk menyebarluaskan informasi dalam pesan gizi seimbang, sehingga semua lapisan masyarakat termasuk remaja siswa sekolah menengah pertama dapat mengetahui pesan-pesan yang terkandung dalam pesan gizi seimbang serta dapat menerapkannya dalam kehidupan seharihari.

Teman sebaya (peer group) merupakan remaja yang memiliki tingkat kematangan yang kurang lebih sama. Mereka saling berinteraksi dan masingmasing memiliki peran yang unik. Remaja cenderung memiliki kelompok-kelompok sebaya. Dalam kelompok tersebut akan berkembang iklim dan norma-norma tertentu. Pada masa ini, remaja lebih mementingkan perannya sebagai anggota kelompok dari pada pola pribadinya. Pada saat yang bersamaan, remaja cenderung memisahkan diri dari orang tuanya (Santrock, 2003).

Remaja memiliki kebutuhan yang kuat untuk disukai dan diterima oleh teman sebayanya. Interaksi diantara teman sebaya sangat berperan penting dalam perkembangan sosial seseorang. Salah satu fungsi terpenting dari teman sebaya adalah sebagai sumber informasi mengenai dunia di luar keluarga. Termasuk dalam hal ini adalah informasi kesehatan. Karena itu, beberapa intervensi kesehatan melibatkan peran teman sebaya dalam menyampaikan pesan kesehatan ataupun membentuk nilai dan perilaku tertentu. Seperti studi yang dilakukan oleh Setyawati di Yogyakarta, menemukan bahwa upaya pencegahan HIV-AIDS pada remaja dapat melibatkan peran teman sebaya. Remaja lebih terbuka dalam membicarakan tentang seks dan perilaku-perilaku berisiko tertular HIV/AIDS. (Setyawati et al., 2015).

Demikian pula yang ditemukan oleh Aisah yang mengkaji pengaruh edukasi kelompok sebaya terhadap perubahan perilaku pencegahan anemia 
gizi besi pada wanita usia subur di Kota Semarang. Studi tersebut menemukan bahwa pengetahuan, sikap dan keterampilan responden tidak dipengaruhi oleh umur dan tingkat pendidikan. Namun dipengaruhi oleh intervensi edukasi teman sebaya. (Aisah, 2008)

Di Makassar, studi yang dilakukan oleh Suriah di Kecamatan Tallo terhadap 60 orang responden berusia 15-19 tahun tentang peran teman sebaya dalam meningkatkan pengetahuan tentang pernikahan dini menemukan bahwa terjadi peningkatan pengetahuan pada kelompok intervensi dibandingkan kontrol. Peningkatan pengetahuan remaja yang diedukasi oleh teman sebayanya juga cukup tinggi. Studi tersebut merekomendasikan pelibatan teman sebaya pada program yang menyasar remaja. (Suriah, 2013)

Teman sebaya menjadi mediator yang cukup prospektif dalam mengupayakan perubahan perilaku pada remaja. Termasuk dalam hal ini adalah perilaku gizi seimbang. Namun, hal penting yang dibutuhkan untuk merubah perilaku adalah melalui peningkatan pengetahuan. Meski pengetahuan yang baik tidak serta merta akan diikuti oleh perilaku yang baik pula. Sebelum remaja bisa menularkan pengetahuan tersebut pada orang lain, maka mereka perlu memperbaiki pengetahuannya sendiri. Penelitian ini dilakukan untuk melihat efektifitas pelatihan edukator sebaya terhadap pengetahuan gizi seimbang pada siswa calon edukator sebaya di SMUN 16 Makassar.

\section{METODE}

\section{Lokasi dan Rancangan Penelitian}

Penelitian ini dilaksanakan di SMUN 16 Makassar. Jenis penelitian yang dilakukan adalah studi intervensi

\section{Populasi dan sampel}

Populasi penelitian ini adalah seluruh siswa kelas $\mathrm{X}$ di SMUN 16
Makassar. Pemilihan sampel dilakukan secara purposive sampling sesuai dengan kriteria inklusi yang ditetapkan. Kriteria inklusi pada studi ini adalah (1). Siswa kelas X dan XI (2). Berkepribadian supel dan menarik (3). Bersedia Mengikuti Pelatihan (4) Bersedia menjadi educator sebaya Berdasarkan kriteria yang telah ditetapkan terpilih 40 siswa

\section{Metode pengumpulan data}

Pengumpulan data dilakukan oleh enumerator terlatih. Data pengetahuan responden diukur dengan kuesioner yang telah divalidasi. Selain itu, dikumpulkan juga data tentang status gizi.

\section{Analisis data}

Data penelitian diolah menggunakan SPSS versi 16. Untuk mengetahui perbedaan pengetahuan responden sebelum dan setelah intervensi digunakan uji $\mathrm{t}$ berpasangan

\section{HASIL}

Berdasarkan tabel 1 terlihat bahwa responden pada penelitian ini paling banyak berusia 15 tahun yaitu $67,5 \%$ dan paling sedikit berusia 16 tahun, yaitu $12,5 \%$. Berdasarkan jenis kelamin, sebagian besar responden adalah perempuan, yaitu $67,5 \%$ dan selebihnya adalah laki-laki yaitu 32,5\%. Berdasarkan agama, responden paling banyak beragama Islam yaitu $82,5 \%$. Berdasarkan suku, responden paling banyak berasal dari suku Bugis yaitu $57,5 \%$, namun ada juga responden yang berasal dari Suku Jawa dan Alor, yaitu masing-masing 2,5\%. Berdasarkan status gizi, sebagian besar responden normal, yaitu $85 \%$, tetapi ada juga yang memiliki masalah gizi. Responden ada yang berstatus gizi kurang, yaitu $7,5 \%$, gizi lebih $2,5 \%$ dan obesitas $5 \%$. 
Tabel 1.

Karakteristik Responden Penelitian

\begin{tabular}{|c|c|c|}
\hline $\begin{array}{c}\text { Karakteristik } \\
\text { Responden }(n=40)\end{array}$ & $\mathrm{n}$ & $\%$ \\
\hline \multicolumn{3}{|l|}{ Usia } \\
\hline 14 & 8 & 20 \\
\hline 15 & 27 & 67.5 \\
\hline 16 & 5 & 12.5 \\
\hline \multicolumn{3}{|l|}{ Jenis kelamin } \\
\hline Laki-laki & 13 & 32.5 \\
\hline Perempuan & 27 & 67.5 \\
\hline \multicolumn{3}{|l|}{ Agama } \\
\hline Islam & 33 & 82.5 \\
\hline Kristen Protestan & 5 & 12.5 \\
\hline Kristen Katolik & 2 & 5 \\
\hline \multicolumn{3}{|l|}{ Suku } \\
\hline Bugis & 23 & 57.5 \\
\hline Makassar & 10 & 25 \\
\hline Toraja & 5 & 12.5 \\
\hline Jawa & 1 & 2.5 \\
\hline Alor & 1 & 2.5 \\
\hline \multicolumn{3}{|l|}{ Status Gizi } \\
\hline Kurang & 3 & 7.5 \\
\hline Normal & 34 & 85 \\
\hline Gizi Lebih & 1 & 2.5 \\
\hline Obesitas & 2 & 5 \\
\hline
\end{tabular}

Berdasarkan tabel 2, terlihat bahwa pengetahuan tentang gizi seimbang yang paling banyak tidak diketahui responden adalah tentang pola konsumsi pangan hewani dan nabati yaitu $52,5 \%$ dan pentingnya aktifitas fisik untuk mencegah penyakit tidak menular yaitu $52,5 \%$. Sedangkan yang paling sedikit tidak diketahui oleh responden, adalah konsumsi beraneka ragam makanan. Pertanyaan yang paling banyak dijawab salah oleh responden adalah pentingnya sarapan untuk mencegah obesitas dan pentingnya membaca label, yaitu $37,5 \%$. Pertanyaan yang paling banyak dijawab benar oleh responden adalah tentang konsumsi beraneka ragam jenis makanan.

Tabel 2.

Pengetahuan Responden tentang Gizi Seimbang Sebelum Pelatihan Edukator Sebaya

\begin{tabular}{|c|c|c|c|c|c|c|}
\hline \multirow{2}{*}{ Aspek Pengetahuan } & \multicolumn{2}{|c|}{ Tidak tahu } & \multicolumn{2}{|c|}{ Salah } & \multicolumn{2}{|c|}{ Benar } \\
\hline & $\mathrm{n}$ & $\%$ & $\mathrm{n}$ & $\%$ & $\mathrm{n}$ & $\%$ \\
\hline Konsumsi makanan beraneka ragam dalam pesan gizi seimbang & 1 & 2.5 & 3 & 7.5 & 36 & 90 \\
\hline Pentingnya ASI untuk bayi & 10 & 25 & 4 & 10 & 26 & 65 \\
\hline Pentingnya konsumsi sayur dan buah untuk mencegah SM & 7 & 17.5 & 2 & 5 & 31 & 77.5 \\
\hline Pola konsumsi pangan hewani dan nabati sesuia pesan gizi seimbang & 21 & 52.5 & 3 & 7.5 & 16 & 40 \\
\hline Pola konsumsi sumber karbohidrat & 8 & 20 & 10 & 25 & 22 & 55 \\
\hline Pola konsumsi lemak & 16 & 40 & 5 & 12.5 & 19 & 47.5 \\
\hline Pentingnya sarapan untuk mencegah obesitas & 15 & 37.5 & 15 & 37.5 & 10 & 25 \\
\hline
\end{tabular}




\begin{tabular}{|c|c|c|c|c|c|c|}
\hline \multirow{2}{*}{ Aspek Pengetahuan } & \multicolumn{2}{|c|}{ Tidak tahu } & \multicolumn{2}{|c|}{ Salah } & \multicolumn{2}{|c|}{ Benar } \\
\hline & $\mathrm{n}$ & $\%$ & $\mathrm{n}$ & $\%$ & $\mathrm{n}$ & $\%$ \\
\hline Pentingnya kecukupan air & 18 & 45 & 13 & 32.5 & 9 & 22.5 \\
\hline Pentingnya membaca label & 3 & 7.5 & 15 & 37.5 & 22 & 55 \\
\hline Pentingnya kebiasaan mencuci tangan & 5 & 12.5 & 2 & 5 & 33 & 82.5 \\
\hline Cara mempertahankan berat badan normal & 9 & 22.5 & 8 & 20 & 23 & 57.5 \\
\hline Pentingnya keanekaragaman makanan & 15 & 37.5 & 9 & 22.5 & 16 & 40 \\
\hline Perilaku hidup bersih untuk mencegah penyakit infeksi & 11 & 27.5 & 7 & 17.5 & 22 & 55 \\
\hline Pentingnya aktivitas fisik & 21 & 52.5 & 8 & 20 & 11 & 27.5 \\
\hline Pemantauan berat badan & 20 & 50 & 2 & 5 & 18 & 45 \\
\hline
\end{tabular}

Berdasarkan tabel 3, terlihat bahwa pengetahuan tentang gizi seimbang yang paling banyak tidak diketahui responden adalah tentang pola konsumsi pangan hewani dan nabati yaitu 22,5\%. Sedangkan yang paling sedikit tidak diketahui oleh responden, adalah pentingnya konsumsi sayur dan buah untuk mencegah SM yaitu $2,5 \%$. Pertanyaan yang paling banyak dijawab salah oleh responden adalah cara mempertahan berat badan normal yaitu $30 \%$. Pertanyaan yang paling banyak dijawab benar oleh responden adalah tentang pentingnya ASI untuk bayi serta pentingnya konsumsi sayur dan buah untuk mencegah SM, yaitu 95\%.

Tabel 3.

Pengetahuan Responden tentang Gizi Seimbang Setelah Pelatihan Edukator Sebaya

\begin{tabular}{lcccccc}
\hline \multirow{1}{*}{ Aspek Pengetahuan } & \multicolumn{2}{c}{ Tidak tahu } & \multicolumn{2}{c}{ Salah } & \multicolumn{2}{c}{ Benar } \\
& $\mathrm{n}$ & $\%$ & $\mathrm{n}$ & $\%$ & $\mathrm{n}$ & $\%$ \\
\hline Konsumsi makanan beraneka ragam dalam pesan gizi seimbang & 6 & 15 & 1 & 2.5 & 33 & 82.5 \\
Pentingnya ASI untuk bayi & 1 & 12.5 & 1 & 2.5 & 38 & 95 \\
Pentingnya konsumsi sayur dan buah untuk mencegah SM & 1 & 2.5 & 1 & 2.5 & 38 & 95 \\
Pola konsumsi pangan hewani dan nabati sesuia pesan gizi seimbang & 9 & 22.5 & 11 & 27.5 & 20 & 50 \\
Pola konsumsi sumber karbohidrat & 2 & 5 & 7 & 17.5 & 31 & 77.5 \\
Pola konsumsi lemak & 5 & 12.5 & 12 & 30 & 23 & 57.5 \\
Pentingnya sarapan untuk mencegah obesitas & 6 & 15 & 4 & 10 & 30 & 75 \\
Pentingnya kecukupan air & 5 & 12.5 & 8 & 20 & 27 & 67.5 \\
Pentingnya membaca label & 4 & 10 & 7 & 17.5 & 29 & 72.5 \\
Pentingnya kebiasaan mencuci tangan & 3 & 7.5 & 5 & 12.5 & 32 & 80 \\
Cara mempertahankan berat badan normal & 1 & 2.5 & 14 & 35 & 25 & 62.5 \\
Pentingnya keanekaragaman makanan & 3 & 7.5 & 9 & 22.5 & 28 & 70 \\
Perilaku hidup bersih untuk mencegah penyakit infeksi & 3 & 7.5 & 3 & 7.5 & 34 & 85 \\
Pentingnya aktivitas fisik & 3 & 7.5 & 3 & 7.5 & 34 & 85 \\
Pemantauan berat badan & 5 & 12.5 & 5 & 12.5 & 30 & 75 \\
\hline
\end{tabular}

Berdasarkan tabel 4, terlihat bahwa setelah pelatihan edukator sebaya, terjadi peningkatan pengetahuan responden pada kategori baik, yaitu dari $17,5 \%$ sebelum pelatihan menjadi $70 \%$ setelah pelatihan, meningkat sebesar 52,5\%. Sedangkan pengetahuan responden yang pada kategori cukup mengalami penurunan, yaitu dari 
$45 \%$ sebelum pelatihan menjadi $25 \%$ setelah pelatihan, menurun sebesar $20 \%$. Demikian pula, pengetahuan responden pada kategori kurang mengalami penurunan juga, yaitu dari $37,5 \%$ sebelum pelatihan menjadi 5\% setelah pelatihan dilakukan, menurun sebesar $32,5 \%$. Dari hasil uji statistic yang dilakukan, menunjukkan nilai $\mathrm{p}=0,000$, yang berarti terdapat perbedaan yang bermakna pada pengetahuan responden sebelum dan setelah dilakukan pelatihan edukator sebaya.

Tabel 4.

Perubahan Pengetahuan Responden Tentang Gizi Seimbang

Setelah Pelatihan Edukator Sebaya

\begin{tabular}{lcccccr}
\hline \multirow{2}{*}{ Pengetahuan } & \multicolumn{2}{c}{ Sebelum Pelatihan } & \multicolumn{2}{c}{ Setelah Pelatihan } & & \\
& $\mathrm{n}$ & $\%$ & $\mathrm{n}$ & $\%$ & Nilai $\mathrm{p}^{*}$ & Interpretasi \\
\hline Baik & 7 & 17.5 & 28 & 70 & & \\
Cukup & 18 & 45 & 10 & 25 & 0,000 & Berbeda \\
Kurang & 15 & 37.5 & 2 & 5 & & \\
\hline
\end{tabular}

\section{*Uji t Berpasangan}

\section{PEMBAHASAN}

Remaja merupakan salah satu fase kehidupan yang berisiko mengalami masalah gizi dan masalah kesehatan terkait. Salah satu penyebab timbulnya masalah gizi dan kesehatan tersebut adalah kurangnya pengetahuan remaja tentang gizi maupun kesehatan secara umum. Informasi gizi maupun kesehatan kadang diperoleh dari berbagai sumber yang belum tentu akurat ataupun informasi yang diterima tidak lengkap atau menyeluruh sehingga dapat menimbulkan kurangnya pemahaman remaja.

Berdasarkan hasil penelitian, tergambar bahwa responden belum banyak yang mengetahui bagaimana pola konsumsi pangan hewani dan nabati yang seharusnya sesuai pola gizi seimbang. Pangan hewani dan nabati perlu dikonsumsi secara tepat dan seimbang. Karena masing-masing sumber pangan tersebut memiliki peran dalam menjadi kesehatan tubuh manusia. Pangan hewani merupakan sumber protein dan lemak serta berbagai mineral penting. Pangan hewani dibutuhkan sebagai sumber Fe dan zink. Konsumsi yang berlebihan pada sumber pangan hewani dapat memicu terjadinya penyakit tidak menular. Kekurangan konsumsi pangan hewani dapat menyebabkan terjadinya defisiensi besi (anemia) dan defisiensi zink (hipozinkemia).

Pangan nabati merupakan sumber utama serat, vitamin dan mineral serta antioksidan. Pangan nabati diperlukan dalam pencegahan penyakit tidak menular. Konsumsi yang berlebihan pada pangan nabati akan menyebabkan terjadinya defisiensi mineral-mineral penting seperti Fe dan Zink, karena pangan nabati biasanya mengandung zat-zat yang menghambat penyerapan $\mathrm{Fe}$ dan Zink. Dilain sisi, konsumsi yang kurang pada pangan nabati dapat memicu terjadinya penyakit degenerative. Serat tumbuhan sangat dibutuhkan untuk mencegah berbagai gangguan metabolic, seperti menjaga kadar gula darah maupun kolesterol. Masalah utama yang sering dijumpai pada remaja adalah mereka tidak suka mengkonsumsi sayur dan buah.

Berdasarkan hasil FGD yang telah dilakukan, remaja tidak menyukai sayur dan buah, biasanya karena tidak tahu 
manfaatnya, tidak suka rasanya yang hambar ataupun karena tidak tersedia di rumah ataupun sekolah. Hasil temuan tersebut serupa dengan studi yang dilakukan pada mahasiswa obesitas di Universitas Hasanuddin. Bahkan dalam studi tersebut ditemukan bahwa meskipun pengetahuan dan sikap responden dalam kategori baik namun pola konsumsi sayur dan buah responden masih kurang dari standar gizi seimbang (Muchtar NL. et al., 2015).

Studi yang dilakukan pada siswa SMAN 2 Rantepao Toraja Utara menemukan bahwa meski remaja telah terpapar dengan informasi tentang pentingnya konsumsi sayur dan buah namun belum dapat meningkatkan konsumsi sayur dan buah pada remaja (Welti et al., 2015). Demikian pula studi yang dilakukan pada remaja siswa SMPN 1 Kesu' Toraja Utara, menemukan bahwa konsumsi sayur dan buah masih dibawah rekomendasi minimum. Selain itu, studi tersebut menemukan adanya hubungan yang bermakna antara sikap dan konsumsi sayur buah pada remaja (Khatima H., et al., 2015)

Aspek pengetahuan lain yang paling banyak tidak diketahui responden adalah pentingnya aktivitas fisik dalam mencegah penyakit tidak menular. Salah satu masalah yang dijumpai pada remaja zaman sekarang adalah kurang beraktifitas fisik. Berbagai kemudahan serta fasilitas yang mereka jumpai dalam kesehariannya, menyebabkan mereka kurang melakukan aktifitas fisik. Penggunaan gadget telah menjadi bagian yang tidak bisa dilepaskan dari keseharian remaja. Padahal, aktivitas fisik sangat dibutuhkan untuk menjaga agar tubuh tetap sehat dan bugar. Terutama untuk mencegah terjadinya penyakit tidak menular. SM berhubungan dengan aktifitas fisik dan sedentary. Pan, dkk, (2008) menemukan bahwa SM lebih sering ditemukan pada remaja yang tingkat aktifitas fisiknya rendah (4,3\%) dibandingkan remaja yang aktifitas sedang $(3,1 \%)$ dan tinggi (2,6\%).Mark, dkk, menemukan bahwa waktu menonton berhubungan dengan peningkatan risiko SM pada remaja. Penemuan tersebut merekomendasikan intervensi gaya hidup sehat pada remaja harus mengikutsertakan komponen yang bertujuan untuk mengurangi waktu menonton (screen time). McMurray, dkk, (2008) menemukan bahwa remaja yang mengalami SM sepertinya 6,08 kali lebih kurang melakukan senam aerobic di waktu kecil dan 5,16 kali memiliki tingkat aktifitas fisik yang rendah.

Aktivitas fisik secara teratur atau rutin memiin efek ringan sampai moderat terhadap penurunan sejumlah risiko gangguan metabolisme, penyakit jantung dan pembuluh darah, dan SM. Aktivitas fisik yang rutin juga mencegah terjadinya diabetes mellitus type 2 serta berpengaruh terhadap berbagai komponen SM seperti memberikan efek positif terhadap resistensi insulin, intoleransi glukosa, dislipidemia, dan hipertensi serta penurunan berat badan (Lakka dan Laaksonen, 2007).

Sejumlah penelitian epidemiologi menunjukkan bahwa aktifitas fisik yang teratur maupun latihan aerobik dapat memperbaiki metabolisme tubuh sekaligus menurunkan risiko SM dan diabetes mellitus tipe 2. Sampai tahun 1990an, aktifitas fisik yang paling banyak direkomendasikan untuk mencegah penyakit tidak menular (degeratif) berfokus pada latihan aerobik kuat. Akan tetapi, berjalan kaki juga merupakan salah satu bentuk aktifitas fisik yang banyak dilakukan di berbagai negara. Hasil penelitian terbaru merekomendasikan bahwa jalan cepat (berjalan kaki dengan cepat, bukan berjalan kaki santai) dan bentuk aktifitas fisik lain yang melibatkan gerakan aerobik intensitas sedang dapat memberikan efek yang sama dengan melakukan latihan aerobik kuat dalam 
meperbaiki metabolisme tubuh dan mengurangi risiko penyakit jantung dan pembulluh darah. Meskipun sejumlah penelitian lain juga menemukan sebaliknya bahwa latihan fisik kuat lebih efektif menignkatkan metabolisme tubuh dan mencegah SM dan penyakit jantung coroner dibandingkan hanya melakukan aktifitas fisik sedang (Lakka dan Laaksonen, 2007). Hal ini menunjukkan bahwa untuk mencegah atau menurunkan risiko SM, setidaknya kita perlu melakukan minimal aktifitas fisik intensitas sedang setiap hari seperti berjalan kaki cepat atau melakukan latihan aerobik sedang.

Sarapan sangat penting untuk mencegah terjadinya obesitas yang merupakan komponen utama dari SM. Sarapan adalah kegiatan makan dan minum yang dilakukan antara bangun pagi sampai jam 9 untuk memenuhi sebagian kebutuhan gizi harian(15-30\% kebutuhan gizi) dalam rangka mewujudkan hidup sehat, aktif, dan produktif. Masyarakat Indonesia masih banyak yang belum membiasakan sarapan. Padahal dengan tidak sarapan akan berdampak buruk terhadap proses belajar di sekolah bagi anak sekolah, menurunkan aktifitas fisik, menyebabkan kegemukan pada remaja, orang dewasa, dan meningkatkan risiko jajan yang tidak sehat. Sebaliknya, sarapan membekali tubuh dengan zat gizi yang diperlukan untuk berpikir, bekerja, dan melakukan aktivitas fisik secara optimal setelah bangun pagi. Bagi anak sekolah, sarapan yang cukup terbukti dapat meningkatkan konsentrasi belajar dan stamina. Bagi remaja dan orang dewasa sarapan yang cukup terbukti dapat mencegah kegemukan. Membiasakan sarapan juga berarti membiasakan disiplin bangun pagi dan beraktifitas pagi dan tercegah dari makan berlebihan dikala makan kudapan atau makan siang. Karena itu sarapan merupakan salah satu perilaku penting dalam mewujudkan gizi
seimbang.Pekan Sarapan nasional (PESAN) yang diperingati setiap tanggal 14-20 Februari diharapkan dapat dijadikan sebagai momentum berkala setiap tahun untuk selalu mengingatkan dan mendorong masyarakat agar melakukan sarapan yang sehat sebagai bagian dari upaya mewujudkan Gizi Seimbang.

Sarapan sehat setiap pagi dapat diwujudkan dengan bangun pagi, mempersiapkan dan mengonsumsi makanan dan minuman pagi sebelum melakukan aktifitas harian. Sarapan yang baik terdiri dari pangan karbohidrat, pangan lauk-pauk, sayuran atau buahbuahan dan minuman. Bagi orang yang tidak biasa makan kudapan pagi dan kudapan siang, porsi makanan saat sarapan sekitar sepertiga dari total makanan sehari. Bagi orang yang biasa makan kudapan pagi dan makanan kudapan siang, jumlah porsi makanan sarapan sebaiknya seperempat dari makanan harian.

Pola makan merupakan perilaku paling penting yang dapat mempengaruhi keadaan gizi. Hal ini disebabkan karena kuantitas dan kualitas makanan dan minuman yang dikonsumsi akan mempengaruhi asupan gizi yang selanjutnya akan mempengaruhi kesehatan individu. Gizi yang optimal sangat penting untuk pertumbuhan normal serta perkembangan fisik dan kecerdasan remaja. Gizi baik membuat berat badan normal atau sehat, tubuh tidak mudah terkena penyakit infeksi, produktivitas kerja meningkat serta terlindung dari penyakit kronis dan kematian dini. Agar tubuh tetap sehat dan terhindar dari berbagai penyakit kronis atau penyakit tidak menular terkait gizi, maka pola makan remaja perlu ditingkatkan ke arah konsumsi gizi seimbang.

Gizi seimbang adalah makanan yang dikonsumsi sehari-hari yang mengandung zat gizi dalam jenis dan jumlah yang sesuai dengan kebutuhan tubuh dengan memperhatikan prinsip 
keanekaragaman atau variasi makanan, aktivitas fisik, kebersihan, dan mempertahankan berat badan normal untuk mencegah masalah gizi. Berbagai definisi atau pengertian mengenai Gizi Seimbang (Balanced Diet) telah dinyatakan oleh berbagai institusi atau kelompok ahli, tetapi pada intinya definisi Gizi Seimbang mengandung komponen-komponen yang lebih kurang sama, yaitu: cukup secara kuantitas, cukup secara kualitas, mengandung berbagai zat gizi (energi, protein, vitamin dan mineral) yang diperlukan tubuh untuk tumbuh (pada anak-anak, remaja), untuk menjaga kesehatan dan untuk melakukan aktivitas dan fungsi kehidupan sehari-hari (bagi semua kelompok umur dan fisiologis), serta menyimpan zat gizi untuk mencukupi kebutuhan tubuh saat konsumsi makanan tidak mengandung zat gizi yang dibutuhkan.

\section{KESIMPULAN DAN SARAN}

Pelatihan edukator sebaya dengan modul edukasi gizi yang dikembangkan pada studi ini berhasil meningkatkan pengetahuan responden tentang gizi seimbang pada kategori baik, yaitu dari $17,5 \%$ menjadi $70 \%$, meningkat sebesar $52,5 \%$, pengetahuan responden pada kategori cukup mengalami penurunan, yaitu dari $45 \%$ menjadi $25 \%$, menurun sebesar 20\%. Pengetahuan responden pada kategori kurang mengalami penurunan juga, yaitu dari $37,5 \%$ menjadi $5 \%$, menurun sebesar 32,5\%. Edukator gizi yang telah dilatih diharapkan dapat menularkan pengetahuan yang dimilikinya kepada teman-teman sebayanya. Selain itu, program-program promosi kesehatan, terutama gizi seimbang harusnya gencar dilakukan di sekolah, mengingat sekolah merupakan tempat membentuk perilaku sehat yang diharapkan akan terus bertahan hingga remaja memasuki fase dewasa

\section{DAFTAR PUSTAKA}

Aisah, S. (2008, Agustus 20). Pengaruh Edukasi Kelompok Sebaya Terhadap Perubahan Perilaku \{encegahan Anemia Gizi Besi pada Wanita Usia Subur di Kota Semarang. Retrieved Januari1 13, 2017, from Universitas Indonesia Library: http://lib.ui.ac.id/detail.jps?id=2043 8042

Jafar, N. 2012. Perilaku Gizi Seimbang Pada Remaja. In: PRODI ILMU GIZI, F. K. M. U. (ed.). Makassar.

Khatima H, Jafar, N, Salam A. (2015, 01 21). Hubungan Perilaku dan Preferensi Dengan Konsumsi Sayur dan Buah pada Remaja SMPN 1 Kesu' di Kabupaten Toraja Utara. Retrieved 01 12, 2017, from Repository Unhas: http://repository.unhas.ac.id/handle /123456789/12568

Muchtar NL, Jafar N, Syam A. (2015, 081 19). Gambaran Pengetahuan, Sikap Gizi Seimbang dan Pola Konsumsi Sayur dan Buah pada Mahasiswa Obesitas. Retrieved 011 10, 2017, from Repository Unhas:

http://repository.unhas.ac.id/handle $/ 123456789 / 15344$

Santrock, J. W. (2003). Adolescence : Perkembangan Remaja. Jakarta: Erlangga.

Setyawati E, Yuningtyas, Meylani. (2015, Maret 182). Strategi Komunikasi Pencegahan HIV-AIDS Dengan Menggunakan Pendekatan Peer Group pada Kelompok Remaja di SMA Daerah Istimewa Yogyakarta (Studi Komunikasi dan Sosiologi Mengenai Pencegahan HIV-AIDS di Kalangan Kelompok Remaja di DIY). Retrieved Januari 1 12, 2017, from http://ejournal.uajy.ac.id/id/eprint/7044 
Suriah. (2013, 10 24). Analysis of Peer Education Towards Knowledge and Attitude of Peer Education About Early Marriage in Makassar, South Sulawesi. Retrieved 1 14, 2017, from Repository Unhas: http://repository.unhas. ac.id/handle/123456789/7687

Welti, Jafar N. Najamuddin U. (2015, 01 212). Hubungan Preferensi dan Keterpaparan Informasi Dengan Pola Konsumsi Sayur dan Buah pada Siswa SMA Negeri 2 Rantepao di Kabupaten Toraja Utara. Retrieved 11 10, 2017, from Repository Unhas: http://repository.unhas.ac.id/handle $/ 123456789 / 12575$ 